\title{
Comments
}

\section{ACCESS TO GOVERNMENTAL INFORMATION IN CALIFORNIA}

Government generates a great deal of information in the course of its operations. To a large extent, this information is crucial to understanding and controlling the decisions of government. A certain amount, however, is vital primarily to the inner workings of the government; its disclosure could cause administrative disruption. Furthermore, some of this information concerns only the private activities of people, and disclosure may substantially harm certain individuals. Consequently, a decision to allow access to governmental information may turn on a delicate balance of interests. ${ }^{1}$

In California, the initial weighing of interests has been done by the legislature. The legislature has dealt separately with information available only during the course of meetings of public officials and information recorded in writings. The basic legislative judgment declaring the public's right of access to ineetings of local legislative bodies was set forth in the Ralph M. Brown Act: "All meetings of the legislative body of a local agency shall be open and public, and all persons shall be permitted to attend any meeting of the legislative body of a local agency ...."2 The legislature subsequently extended this riglit to meetings of state agencies. ${ }^{3}$ A similar policy was established for governmental writings: "The public records and other matters in the office of any officer, except as otherwise provided, are at all times during office hours open to inspection of any citizen of the State." ${ }^{\prime 4}$ The right of access to governmental information in California has been generally formulated by the judicial, legislative, and executive interpretation and developinent of these statutes. This Comment will explain and evaluate this development.

\section{I}

MEETINGS OF PUBLIC BODIES

Top level commissions and committees examine and determine basic government policies. Though their decisions usually are effectively made known to the community, intelligent evaluation of the operation of any

${ }^{1}$ Writers have argued that access is part of a constitutional right to know; but the right to know exists mainly as a rallying phrase. See WigGins, Freedom or SECRECY (rev. ed. 1964), Cross, The People's Rtgrt to Krow (1953), and Note, Open Meeting Statutes: The Press Fights for the "Right to Know," 75 HARv. L. REv. 1199 (1961).

2 CAL. Gov't CODE \& 54953.

3 Cal. Stat. 1957, ch. 2170-2235, and Cal. Stat. 1959, ch. 842-62.

4 CAI. Gov't CODE § 1227. 
body requires that the premises on which decisions are based also be made public. One manner of satisfying this need is to allow the public to attend all meetings of these bodies. To this end, the legislature enacted the Ralph M. Brown Act, ${ }^{5}$ and a series of statutes dealing with meetings of state agencies. ${ }^{6}$ The Brown Act and the state agency statutes require that all "meetings" be open and public. ${ }^{7}$ To determine the scope of this requirement, it is first necessary to establish a definition of the term "meeting."

There is a spectrum of gatherings of agency members that can be called a meeting, ranging from formal convocations to transact business to chance encounters where business is discussed. However, neither of these two extremes is an acceptable definition of the statutory word "meeting." Requiring all discussion between members to be open and public would preclude normal living and working by officials. On the other hand, permitting secrecy unless there is formal convocation of a body invites evasion. In formulating a definition of "meeting" the public's need for access to information must be balanced against the official's need to act in an administratively feasible manner. Public offiicals must be able to become acquainted with community problems in depth, to test ideas without becoming publicly committed to them, and to feel out opposition and begin compromise. The problem of the courts, legislature and executive department is to find a definition of "meeting" that can accommodate officials and still protect the public's access to information.

\section{A. Proceedings that must be Open and Public}

Adler v. City Council" is the only appellate opinion to define "meeting" as used in the Brown Act and thereby to attempt an accomniodation of the needs of the public for access to information and the need of the official for some nondisclosure. ${ }^{9}$ In Adler, a citizen sued to mvalidate a zoning variance on the ground that the variance was given at a secret meeting, contrary to the mandate of the Brown Act." The court fonnd no "meet-

5 CAL. Gov'T CODE $\$$ 54950-60.

0 Cal. Stat. 1957, ch. 2170-2235, and Cal. Stat. 1959, ch. 842-62.

7 E.g., CaL. Gov'T CODE $§ 54953$.

8184 Cal. App. 2d 763, 7 Cal. Rptr. 805 (1960).

9 Huntington Beach Union High School Dist. v. Collins, 202 Cal. App. 2d 67t, 21 Cal. Rptr. 56 (1962), cert. denied 371 U.S. 904 (1962), was the only other appellate level opinion dealing with a violation of the Brown Act. The court did not cite Adler; it nerely said that there may have been a technical violation of the Brown Act and the petitioner suffered no prejudice by the action of the body in secret session. The case did not add anything to the meaning of the Brown Act.

${ }^{10}$ Zoning changes in Culver City were made by the city council after recommendation by the planning commission; the commission acted only in an advisory capacity. In Adler, before the changes had been formally proposed, the promoter took the menibers of the 
ing" was held, and that consequently there was no violation of the act.11 The Adler court defined "meeting" to inclucle only gatherings where members sit "as a joint body at an authorized meeting duly assembled . . . in existence as a board of entity." 12 This definition was taken from a Florida case interpreting a similar statute; the Florida court's definition was based on the assumption that the Florida Legislature intended the term "meetings" to refer only to formal assemblies authorized to transact business. ${ }^{13}$ The California Legislature explicitly stated a contrary intent in the Brown Act. That act applies not only to gatherings where action is taken to bind the body, but also where there are only deliberations. ${ }^{14}$ Yet under the Adler definition, any time a local legislative body desires to prevent the public from knowing what action is to be taken or what deliberation is taking place, it can gather in an informal session.

The Adler court reasoned that if anything less than a formal meeting were the target of the act, no practical line could be drawn. Furthermore, exchange of information would be impeded, viewing of property by the council would be handicapped, and it would be impossible for the council to confer with individuals having expertise in municipal problems. ${ }^{15}$ These arguments are specious. All exchanges of information between members of a council would not have to be restricted to public gatherings if "meeting" were inore broadly defined. A practical line can be drawn with gatherings less than a formal ineeting as the target. ${ }^{16}$ In addition, viewing property is not so complex as to preclude attendance by the public. Furthermore, individuals particularly qualified to speak on municipal ques-

commission to dinner at a country club for a private discussion. The commission subsequently held public hearings on the proposal and recommended to allow the change if fourteen paragraphs of conditions were met. The city council approved the zoning variance and eased the conditions, commenting that the commission "unnecessarily penalized" the applicant. 184 Cal. App. $2 d$ at 766-67, 7 Cal. Rptr. at 807. A private citizen opposing the zoning change brought suit to invalidate the variance. He alleged that the dinner gathering of the commission violated the Brown Act. Id. at 767, 7 Cal. Rptr. at 807.

11 The superior court based its conclusion that there was no violation of the Brown Act on the finding that "no action, commitments, or promises, or suggestions of actions, commitments or promises were made ... nor was said proposed rezoning . . . dehberated upon at said meeting." Id. at 767, $7 \mathrm{Cal}$. Rptr. at 808 , as required for the gathering to coine within the Brown Act.

12 Id. at 772, 774, 7 Cal. Rptr. at 811, 812. Adler also used other grounds for the decision: The commission as an advisory board did not come under the Brown Act, id. at 771-72, $7 \mathrm{Cal}$. Rptr. at 810-11; the dinner gathering had hittle if any influence on the decision of the city council, especially since the commission placed harsher restrictions on the variance than did the council, $i d$. at 769, 7 Cal. Kptr. at 809; and the judicial remedy of invalidation was not available, $i d$. at $775,7 \mathrm{Cal}$. Rptr. at 813.

13 Turk v. Richard, 47 So. 2d 543, 544 (Fla. 1950).

14 CAI. Gov'T Code § 54950.

16184 Cal. App. 2d at 770, 7 Cal. Rptr. at 810 .

16 See text accompanying notes 32-38 infra. 
tions should not be prevented from presenting their thoughts to the community. The court ignored the mandate of the Brown Act and formulated a definition that would primarily protect the official, and would not safeguard the information-seeking interests of the general public.

Subsequent to Adler, in 1961, the Califorma Legislature was presented with a proposal to amend the Brown Act to add: "Meetings shall be open even if held for the purpose of discussion and no action is taken or no decision is to be made on the subject under consideration." ${ }^{\prime 17}$ This bill was killed in committee. ${ }^{18}$ The legislature did, however, enact amendments that were designed to counteract Adler in some instances. "Legislative body" was extended to include planning commissions and "other permanent boards or commissions of a local agency."19 A section was added providing that any interested person may commence an action by mandamus or injunction to prevent violations or threatened violations of the act. ${ }^{20}$ "Action taken" was defined, ${ }^{21}$ and nembers of bodies covered by the act who knowingly attended a meeting which was held in violation of the act and at which there was "action taken" were declared guilty of a misdemeanor. ${ }^{22}$ The legislature did not explicitly overrule the Adler decision by these enactments, but, as the Attorney General of California has argued, there are strong indications that this is the result.

The Attorney General has consistently interpreted the Brown Act's term "meeting" in a manner that promotes public access to information. ${ }^{23}$

17 Assembly Bill 127, Cal. Legislature, Regular (General) Sess. (1961).

18 There is some doubt that the bill would have changed the result of Adler had it been enacted. The Adler decision defined "meetings." The bill used the word "meeting" without indicating there should be any change from the Adler rule.

19 CAL. Gov'T CODE $\$$ 54952.5. In Government Code $\$ 54952$, the legislature added that "legislative body" means any "committee, or other body on which officers of a local agency serve in their official capacity as members and which is supported in whole or in part by funds provided by such agency ...." The meaning of this clause is obscure. Possibly, it covers semi-private charity or public service bodies coming under the requirements stated. However, it is also possible that this requires all committees of the main body of the agency to hold open and public meetings. If this is so, another major means of evading the goals of the Brown Act would be unavailable.

20 CAI. Gov'T CODE $§ 54960$.

21 CAI. Gov'T CODE § 54952.6.

22 CAL. Gov't CODE $§ 54959$.

23 Two opinions of the Attorney General written prior to Adler concluded that the act covered more than just formal meetings of local legislative bodies. In the first, "council conferences," where members of the city council met as a committee of the whole in executive session prior to the formal, public meeting, were said to be within the act. 27 Ops. CAI. ATr'y Gen. 123 (1956). The second opinion extended coverage of the act to any committee composed of at least a majority of the nnembers of the local legislative body gathering to deliberate for the purpose of determining an action to be taken at a later meeting of the body. 32 OPS. CAL. ATT'Y GEN. 240, 244 (1958). These conclusions were virtually ignored by the Adler court.

It is important to evaluate the relative weight of the Attoruey General's opinions, for 
He found in the 1961 legislative changes of the act the requirement that some informal city council sessions be open and public, ${ }^{24}$ and concluded that executive sessions of council nnembers meeting with the city manager to review the formal agenda for the purpose of "providing information" to the council were meetings covered by the Brown Act. ${ }^{25} \mathrm{He}$ argued that the strengthening of the act in other respects affected the question of what meetings are covered, noting that it is improbable that the legislature would adopt amendments strengthening the act and simultaneously weaken it by adopting Adler's definition of "meeting." 26 Furthermore, he concluded that the legislature's non-action on the proposal to cover "discussions" in the open and public requirement did not mean that Adler's definition was adopted. ${ }^{27}$

Though the result of the Attorney General's opinion seems correct, the reasoning involved does not satisfactorily dispose of the 1961 legislation. To examine this question, one should go to the statutorily defined term "action taken," for where there is "action taken," the act can be read to require an open and public meeting. "Action taken" is defined in the statute as a collective decision, commitment or promise to make a decision by a majority of the members of a legislative body, or an actual vote on a resolution by a majority of the members when sitting as a body or entity. ${ }^{28}$ Though the statute does not explicitly state that the collective promise may be made at an informal gathering, this is strongly implied by the distinction made between situations where members of the body act as an entity and where they act other than as an entity.

One writer has argued that the definition of "action taken" does not compel an interpretation of "meeting" different from that in Adler. ${ }^{20}$

they are a major source for investigating problems relating to public disclosure in California. One would not ordinarily attribute great weight to the opinions since, althougl the drafters of these opinions are lawyers, they do not bave the experience nor the authority of the judiciary. Moreover, the Attorney General acts as counsel for the state government apparatus and would tend to look more favorably on the cause of the official than might a completely dispassionate party. However, in the present situation the opinions miglit arguably be given more weight than usual. The problems raised often do not reach the courts, and consequently the Attorney General is frequently the only source of published reasoning and decisions to guide official action. More importantly, in the public meeting area, the Attorney General has not acted as the protector of the bureaucrat, but rather has consistently prodded the agencies involved to be more open in their activities.

2442 Ops. CAL. ATT'X Gen. 61 (1963).

$25 I d$. at 68.

26 Id. at 64-67.

27 Id. at 67. A further opinion bas, consistent with the development of the Attorney General's position, said that regular luncheon meetings between two city councils, where questions of importance concerning the two councils were discussed, were subject to the Brown Act. 43 Ors. CaI. ATT'y Gen. 36 (1964).

28 CAL. Gov'T CODE § 54952.6.

29 Herlick, California's Secret Meeting Law, 37 C.A. S.B.J. 540 (1962). 
"Action taken" appears in the section making it a misdemeanor knowingly to attend a meeting where action is taken in violation of the provisions of the chapter; the writer reasons that there can be no violation unless a "meeting" is attended, and the definition of meeting was formulated in Adler. ${ }^{30}$ But this argument iguores the statutory distinction between the body acting as an entity and not as an entity. It also ignores the implications of the use of action taken in another section of the act. ${ }^{31}$

The act provides that "it is the intent of the law that ... actions be taken openly and ... deliberations be conducted openly." ${ }^{32}$ It also provides that "all ineetings . . . shall be open and public." 33 It is reasonable to consider these statements as complementary. "Meetings" required to be open and public would be gatherings where there is "action taken" or "deliberation." "Action taken," as defined by the legislature, may occur at other than formal gatherings of the legislative body. Therefore, the gatherings required by the act to be open and public include more than those defined as "meetings" in Adler.

The goal in requiring that deliberations take place only at meetings that are open and public is that committee members make a conscious effort to air viewpoints on eacli issue so that the community can understand on wliat premises decisions are based, add to those premises whenever necessary, and intelligently evaluate and participate in the process of government. This does not mean that all discussion must be in public. For example, political horsetrading is a necessary fact of viable government. Much of this inust be in private for it to be effective. Yet when secret horsetrading becomes the only means of contesting political viewpoints, the community is left out of the decision process. A method inust be found to accommodate the needs of the legislative body with the needs of the public.

Activities that constitute "deliberation" have not been defined by the Attorney General, the legislature or the courts. The Attorney General has set forth some basic rules describing gatherings subject to the Brown Act, but these rules fail to determine adequately when deliberations covered by the act occur. The Attorney General lias said that only a gathering of at least a majority of the members of a local legislative body comes under the act, ${ }^{34}$ and the "mere social attendance by a majority of the members of a ... local governing body ... would not constitute a meeting subject to the Brown Act." ${ }^{135}$ These rules cannot effectively prevent evasion of

\footnotetext{
30 Id. at 546.

31 CaI. Gov't Code $\$ 54950$.

32 Ibid.

33 CaL. Gov't Code § 54953.

3432 Ors. Cat. AtT'y Gen. 240 (1958).

3543 Ors. Car. Atr'y Gen. 36, 38 (1964).
} 
the open meeting goals. Less than a majority may control the actions of a particular body: Frequently a two-thirds vote is required for a measure to pass; the minority one-third is then effectively in control and the open meeting goal would require its meetings to be public. To say that mere social gatherings will never come under the open meeting requirement misses the point that collective commitments and deliberation can occur under all conditions.

The legislature has had difficulty with defining the activities that should take place in public ineetings. ${ }^{36}$ Definitions of "deliberation" are elusive; finely drawn lines invite evasion. ${ }^{37}$ The problem should not be seen as one of drafting a statutory definition that can cover all situations where public gatherings are required. The Brown Act is not designed to fix the boundaries of public activity of officials. Rather it is designed to remind them that they have a public responsibility and to encourage them to act openly when they might tend to be secretive. An explicit recognition by the legislature of the responsibilities of the official miglt be the best way to work with the term "deliberation." A section could be added to the Brown Act to read: "Tlie purpose of this act is to ensure that the decisions and premises of decision of any local legislative body are publicly articulated. To achieve this purpose, deliberations of such bodies shall be conducted in open and public meetings."38 This addition to the statute should provide a flexible guide to agencies and courts for determining when gatherings must be open and public. With this addition, a sharp line

${ }^{36}$ In the 1961 and 1963 General Sessions of the legislature, bills were introduced that seemed to grapple with this problem, but they did not get beyond committee. Assembly Bill 127, Cal. Legislature, Regular (General) Sess. (1961); Assembly Bill 946, Cal. Legislature, Regular (General) Sess. (1965).

37 Unless every business conversation between members of local legislative bodies is to be open and public, meetings between sets of two and three people, one man missions contacting each member, and telephone calls are all methods to keep dehiberations secret when the mandate for open and public meetings is structured in terms of the number of people present at a gathering.

38 Suggested statutory changes are:

(1) Add to the end of the first paragraph of CAI. Gov'x CODE § 54950: "The responsibility of the representatives of the people is to ensure that the premises of government decision are not kept from the public."

(2) Add CAI. Gov't CoDE § 54953.1: "Meetings under this act occur when there is a gathering of members of a local legislative body at which there is 'action taken' as defined by this act or at which there is 'deliberation.' The purpose of this act is to ensure that the decisions and premises of decision of any local legislative body are publicly articulated. To achieve this purpose, dehiberations of such bodies shall be conducted in open and public meetings."

(3) Amend CAL. Gov't CoDE § 54959 to read: "Each member of a legislative body who attends a meeting of such legislative body where action is taken or deliberation is conducted in violation of any provision of this chapter, with knowledge of the fact that the meeting is in violation thereof, is guilty of a misdemeanor." 
is not set up which would invite evasions. Evasions possible under the present criteria of the Attorney General would be less likely. Each situation would have to be evaluated on the basis of its particular facts, and consequently members of the legislative bodies would be induced to rethink their responsibilities as representatives.

The considerations discussed with respect to the Brown Act also apply to the statutes requiring that all meetings of specified state agencies be open and public. ${ }^{39}$ The language of the pertinent clauses is nearly identical to the Brown Act, ${ }^{40}$ and legislative history does not seem to suggest that coverage is intended to be different from the Brown Act. ${ }^{41}$ Further, the basic policy statements of the Brown Act defining the gatherings required to be open and public can be read to apply equally to the state agencies. ${ }^{42}$ Therefore, informal meetings of state agencies where action is taken or where there is deliberation probably must be open and public. ${ }^{43}$

\section{B. Statutory Exceptions to Coverage of Gatherings}

Though it is important to have government bodies operate in public, it is sometimes necessary for the effective operation of government that there be meetings free from public scrutiny. The Brown Act provides that executive sessions may be held to consider the appointment, employment, or dismissal of a public officer or employee, unless the einployee requests a public hearing. ${ }^{44}$ Presumably the rationale of this section is that government employees should not be put in a more public position than employees of a private organization when their personal attributes are being discussed. Yet it may be desirable in some cases to have public sessions to consider such matters; the airing of qualifications and even of "dirty linen" may be necessary to preserve citizen control of the operation of government. The Brown Act recoguizes this and provides that the secret session is not mandatory. The body may operate in public, and any secret session can only be held durmg a regular or special meeting, as defined

89 Cal. Stat. 1957, ch. 2170-2235, and Cal. Stat. 1959, ch. 842-62.

40 Compare Cat. Gov't Code \& 54953 with, e.g., Cat. Lab. Code \& 146, Cat. Pub. Resources Code § 8609, and Cal. Bus. \& Prof. Code § 8524.5.

41 Cf. Pickerell and Feder, Open Public Meetings of Legistative Bodies-CaltForkJA's Brown ACr, 40-42 (1957 Legislative Problems No. 7. Bureau of Public Administration, Unversity of California, Berkeley). The authors lave compiled relevant background on open meeting legislation.

42 CAL. Gov'T CODE $\$ 54950$, which declares the legislature's intent that actions taken and deliberations of public bodies are to be open and public, and CAL. Gov't CoDE § 54952.6, which defines "action taken," apply to state agencies.

43 For example, The California Administrative Proceđure Act, CAL. Gov'x CoDE \$§ 11370528 , provides for a limited form of open meetings for state agencies engaged in rule making in CAL. Goy't CODE $\$ 11425$.

44 CAL. Gov't Code $\$ 54957$. See generally, 40 Ops. Cat. Art'y Gen. 4 (1962). 
by the act and as "noticed" under its requirements. ${ }^{45}$ Thus, the community will be informed of the executive session and can exert effective pressure to keep the meeting open.

Executive sessions to consider "matters affecting the national security" are also permitted by the Brown Act. ${ }^{46}$ There is no requirement that the matter would adversely affect the national security were the meeting to be held in public. The statute does not specify who has the authority to determine what affects the national security and what are the criteria for the determination. Nor is there an explicit requirement for holding these sessions "during" a regular or special meeting. ${ }^{47}$ To ensure the community is informed of the activities of the legislative body, there should be such an explicit requirement. Also, the determination of what affects the national security is not an appropriate function for a local agency, given its limited experience and information. Only the national government should determine when interests of the national security require secrecy. ${ }^{48}$ To prevent evasion of the public meeting policy, these questions should be resolved by the legislature. ${ }^{49}$

Statutes requirmg open and public meetings for a large number of state agencies have been enacted by the legislature. ${ }^{.0}$ Some of these statutes explicitly permit executive sessions for deliberation on granting

45 CAI. Gov't Code $\$ \$ 54954-57$.

46 CAT. Gov'T CoDE $\$ 5495 \%$.

47 But see 43 Ops. CAL. ATr'y GeN. 79, 80 (1964) which states that it is "clear that executive sessions are permitted only during regular or special meetings for which adequate notice has been given as required ...."

48 Cf. DeGregory v. Attorney Gen. of New Hampshire, 383 U.S. 825 (1966). A determination by the federal government that interests of national security require secret sessions would be made in the course of the existent system for classification of information. Were the local body to deal with some problem involving classified information, one may assume the fact and degree of classification would be made known to the body so that it would not bold an open and public session using the particular information.

49 There is another type of executive session that may be allowed under the Brown Act. The Attorney General has concluded that the attorney-client privilege of CaI. CODE or CIv. Proc. \& 1881(2) may be extended to consultations of city attorneys with their councils when the public interest would otherwise be adversely affectcd. 36 OPS. CAL. ATr'Y GEN. 175 (1960). The decision was premised on the belief that the Brown Act was not intended to give an advantage to an "adversary of the people" in litigation, and therefore did not require disclosure of bargaining limitations and litigation strategy. However, the statute says that "the provisions of this chapter shall apply to the legislative body of every agency notwithstanding the conflicting provisions of any other state law." Car. Gov' $T$ CODE $\$$ 54958. It would follow from this statement that the legislature has decided the advantages of actions and cleliberation in puhlic outweigh the disadvantages. Two counterarguments may be made: A conference with the city attorney is not "deliberation;" and mandamus is the proper remedy to force a meeting to be opened to the public, and the writ will not issue if severe public detriment will result, see note 98 infra.

50 Cal. Stat. 1957, ch. 2170-2235; Cal. Stat. 1959, ch. 842-62. 
and revocation of licenses and for preparing, approving, grading or administering examinations; others have no provision for executive sessions. ${ }^{b 1}$ It is arguable that the legislature strongly implied no executive sessions were to be allowed under the latter statutes: Both sets of statutes were enacted together, ${ }^{52}$ so there was probably a conscious omission of an executive session provision for the latter set. Furthermore, one cannot argue that the Brown Act provisions allowing executive sessions apply to these agencies. Legislative history indicates there can be no transfer of Brown Act provisions to state agencies unless a section specifies such applicability; ${ }^{53}$ the Brown Act's executive session provision does not specifically apply to state agencies. ${ }^{54}$

The state agency statutes could be read to imply that all meetings shall be open and public only when the public interest will not be adversely affected. ${ }^{55}$ Practically speaking, only the agency is available to make this decision. However, if the decision on adversity is left to the agency, it would be able to avoid the open meeting policy. The members would be put in the position of resolving the conflict between their interest in secrecy and the community interest in access to information. In addition, there could be no totally effective judicial remedy for abuse. Once a meeting has been held in secret and information has been exchanged, the basic harm has been done. The information cannot be recalled and actions taken as a consequence of this information cannot be erased. Even if a court required repetition of the meeting, the injury to the public would not be completely repaired. Therefore, the agency should not weigli the public interest in access to meetings. ${ }^{56} \mathrm{New}$ statutory enactments similar to the Brown Act provisions specifying the allowable executive sessions are needed.

51 The statutes are written in essentially three forms: "All meetings of the board shall be open and puhlic." CAL. LAB. CODE \$ 146; "All meetings of the board shall be open and public, and all persons shall be permitted to attend any meetings of the board" CAx. PUB. Resources CODE $\$ 8609$; "All meetings of the board shall be open and public, except that the board may hold executive sessions to: (a) Deliberate on the decision to be reached ... in accordance with Chapter 5 (commencing with Section 11500), Part 1, Division 3, Title 2 of the Government Code. (b) Prepare, approve, grade or administer examinations." CaL. Bus. \& Prof. Code \$ 8524.5.

52 Cal. Stat. 1957, ch. 2170-2235, and Cal. Stat. 1959, ch. 842-62.

53 PiCKERELL AND FEDER, op. cit. supra note 41.

54 CAI. Gov'T CODE $\$ 54957$.

$55 C$. note 101 infra.

56 However, the California Administrative Procedure Act, Cax. Gov'r CoDE \$§ 11370-528, gives state agencies discretion to determine that an emergency exists, and consequently that rules must be established without the use of public notice and argument. CAL. Gov'T CodE $\$ \$ 11421-22.1$. To prevent abuse of this procedure, Government Code $\$ 11422.1$ restricts the rules so established to a life of 120 days unless the agency thereafter complies with the full notice and meeting procedure. 


\section{The "Open and Public" Requirement}

Open and public means more than the right to attend; it also means that there is a right to participate without undue restriction. ${ }^{57}$ Participation requires sufficient notice to the community. Although, the Brown Act provides for sucl notice, ${ }^{58}$ there are few statutory requirements for notice of meetings of state bodies. ${ }^{59}$ Can the agency fail to give notice, unlock the doors to the cliamber, announce the meeting to be open and public,

57 Attendance at meetings cannot be conditioned on registration at the meetings, Car. Gov'T CODE \$ 54953.3, nor can a body require a person who claims to speak on behalf of an organization to disclose publicly the names of the members of such organization as a condition of addressing the body. 46 OPS. CAL. AIr'Y GEN. 4 (1965). As long as the riglits of others in the audience are not infringed, a city council cannot bar the tape recording of council proceedings by a private citizen. Nevens v. City of Chino, 233 Cal. App. 2d 775, 44 Cal. Rptr. 50 (1965). Since the tape could immediately be given to a radio station for broadcast, and since modern electronic equipment might be able to bandle a "live" transmission with as little disturbance as would come from a tape recorder, permitting broadcast of meetings might now be a part of the open and public requirement. Contra, 38 OfS. CaL. ATT'y GeN. 52 (1961), based on "disturbance" reasoning. A reporter has no more right to attend a public meeting than any other member of the public, and his attendance does not allow exclusion of other persons. 46 OPS. CoL. ATT'y GeN. 170 (1965). Therefore, if a broadcast of the meeting were permitted, the public could not be excluded on the basis that the broadcast created the necessary openness to comply with the act.

58 The time and place of regular meetings are to be establisbed by rule of the body. CAL. Gov'T CODE § 54954. Presumably, the public will be able to learn of them by contacting the body itself; and once the information is learned, there is no need for further contact. The time and place of adjourned meetings are to be provided in the order of adjournment. CAL. Gov'T CoDe § 54955. Special meetings require a twenty-four lour written notice to members and, if requested, to media. CAI. Gov'T CODE \$ 54956. The act does not explicitly provide notice requirements for emergency meetings. However, there is an easy solution for a council that must bold an emergency meeting before twenty-four hours clapse. Any member may waive the formal notice requirement for special meetings, and notice to the media must be given only if there is a written request on file. CAx. Gov'T CoDE $\$ 54956$. Were a genuine emergency to occur, it is likely that any member not able to attend would waive his right to notice and any communication organ would withdraw its request, especially since both would have to be contacted for waiver before the meeting and thus would be sure of being informed of its taking place. With the present emphasis on instant news reporting, it is doubtful that any real emergency would not be fully reported to the public immediately.

59 Compare, e.g., Cax. Educ. Code $\$ 109$ (State Board of Education), and Car. Bus. \& Prof. CODE 2849 (Board of Vocational Nurse Exanniners) providing for notice of special meetings only to members of the board, with CAL. Bus. \& PROF. Code $\S 2107$ (Board of Medical Examiners) providing for newspaper publication of notice of special meetings twice a week for two weeks preceding each meeting, and CAL. AGRTC. CODE \& 745.6 (Dairy Council) providing for notice to any interested person who requests it.

Since a state body often meets at irregular intervals and at different locations, a single resolution setting the time and place of regular meetings is inadequate. Compare, e.g., CaL. Gov'x CODE \& 15609 (State Board of Equalization), providing for monthly meetings at the State Capitol, with Car. Bus. \& Prof. Code $\S 10056$ (Real Estate Commission), providing that the commission must meet once each quarter "at such place in California as it may designate." 
and thus satisfy the public meetings requirements? ${ }^{60}$ If this were the case, agencies would hold secret, though formally "public," sessions with impunity. However, this is not the case, and the agencies covered by the statutes have indicated that the statutes have important "openness" consequences. ${ }^{11}$

Implicit in the statutes is the directive that reasonable notice of meetings be given. Criteria by which the reasonableness of notice may be judged can be found in the California Administrative Procedure Act. ${ }^{62}$ This act establishes notice requirements for rule-making and adjudicative meetings of many state agencies; it thereby arguably indicates a course to be taken for agency meetings it does not control. A minimunı of two weeks notice of meetings, distributed in a manner best calculated to reach the general and known-to-be interested public, should be given.$^{63}$ The size of the state and the tinie needed to ensure that conımunication is effective requires sucl a system. Where sessions must be held within a shorter period, notice should be sent by special delivery mail to persons who have evinced an interest in the problems on the agenda, and to persons who have requested such notice in advance. Use of the general news and special trade media might also be appropriate. The shorter the time period between notice and ineeting, the more extensive and more accurately placed inust be the notice. When bona fide ennergency situations require immediate action, the agency should meet after special notice to the news and trade niedia. However, immediately after the emergency ineeting, notice should be disseminated in the usual manner and the agency should

${ }^{60}$ Alva v. Sequoia Union High School Dist., 98 Cal. App. 2d 656, 220 P.2d 788 (1950) could be read to say that it is sufficient to merely unlock the doors. In Alva, the dismissal of several teachers by the school district was challenged because the board allegedly did not conform to pre-Brown Act statutory open meeting requirements. After a series of special board meetings behind closed but unlocked doors, dismissal notices were sent to the petitioning teachers. Another special meeting, for which adequate notice was given, was then held where all teachers involved were given an opportunity to present their cases. The trial judge concluded that the special meetings complied with the statutory requirements because the door was not locked and because the board could have retired to executive session had the meetings been attended by the public. The appellate court affirmed saying that there was ample evidence for the conclusion that the meetings were open. Though this statement might be read to require only unlocked doors for compliance with open and public requirements, the emphasis of the appellate court on the "cure" by the final meeting prohibits such a conclusion. Implicit in the court's idea of a cure is a requirement of reasonable notice.

61 This can be seen by following the history of Assembly Bill 2138, Cal. Legisiature, Regular (General) Sess. 1963. At least one state agency, the State Social Welfare Board, has interpreted the scope of these statutes as being identical to that of the Brown Act. See tenBroek, Welfare in the 1957 Legislature, 46 CarIF. L. Rev. 331, 353 (1958). See also id. at 352-61 for a very interesting evaluation of the open meeting requirement by this former chairman of the State Social Welfare Board.

62 CAL. GOv'T CODE $§ 11370-528$.

e3 Cf. CAL. Gov'T CODE §§ 11423. CaI. Gov'T Code $\S \S 11505,11509$. 
meet to reexamine its emergency actions. ${ }^{64}$ Though this practice is capable of abuse, lack of provisions for emergency meetings invites evasion of the open meeting statutes. Since the notice requirements of the Administrative Procedure Act do not cover all state agency meetings, and since that act is not totally geared to the needs of open and public meetings, the legislature should specify notice requirements for the state agencies.

\section{Remedies for Violation of the Open Meeting Statutes}

The Brown Act specifies two remedies for violation of the open meeting requirement: criminal prosecution of agency members, ${ }^{65}$ and injunction or mandamus to prevent violations. ${ }^{66}$ The state agency statutes specify no remedies, ${ }^{67}$ but the same two are made available by other statutes. ${ }^{68}$

The criminal penalties are probably irrelevant. The reported cases do not indicate there have been any misdemeanor prosecutions, quite possibly because criminal penalties are too great a sanction. ${ }^{60}$ Surely the open meeting requirements are not designed to make criminals of our representatives, but to imduce them to more public action.

The mandamus remedy is predicated on the ability of the one bringing the action to discover the violation before it occurs and prove it. Truly "secret" meetings are not easily discovered beforehand, and the main use of this remedy will be to enjom those meetimgs souglit to be held in spite of public protests.

Argnably, a citizen can sue to enjoin an agency from carrying out a resolution or other action taken in a meeting that violated the command of an open meeting statute, since the act occured at an illegal meeting. ${ }^{70}$ However, the Adler court held that the prescribed criminal penalty for violations of the Brown Act precluded all other remedies and left private

${ }^{04}$ Cf. CAL Gov'T CoDe $\S \S 11422(c), 11422.1$.

65 CaL. Gov't Code $\$ 54959$.

06 CAL. Gov'T Code $\$ 54960$.

67 E.g., Cal. Stat. 1957, chs. 2170-2235; Cal. Stat. 1959, chs. 842-62.

08 Misdemeanor: CaL. Gov't Code § 1222; CaL. Penr. Code § 177. Mandamus: CaL. Code of Crv. Proc. \& 1085, and $c f$. Gogerty v. Coachella Valley Junior College Dist., 57 Cal. 2d 727, 371 P.2d 582, 21 Cal. Rptr. 806 (1962).

${ }^{69}$ See Note, Open Meeting Statutes: The Press Fights for the "Right to Know," 75 HARv. L. REv. 1199, 1211 (1962).

70 Both Idaho and Illinois have declared void action taken at meetings when public notice required by statute was not given before the meeting. Gilbert v. Canyon County, 14 Idaho 429, 94 Pac. 1027 (1908): People ex rel. Dooley v. New York Ci. \& St. L. Ry., 368 IIl. 536, 15 N.E.2d 297 (1938). And ef. State ex rel. Porter v. Headlee, 19 Wash. 477, 53 Pac. 948 (1898); Kleimenhagen v. Putnam County, 143 Fla. 134, 196 So. 465 (1940).

For a vigorous exposition of the "invalidation" position, see Duncan, "Open Meeting Statutes in the United States," address before the Local Government Law Section, American Bar Association, August, 1962, San Francisco, California. 
persons with no right to such injunctive relief. ${ }^{71}$ The basis for this holding was faulty. All but one of the cases relied on by the court involved suits contending that private contracts were invalid because of breach of a criminal statute. In each case, the court held the criminal penalty was the only penalty to be applied; the contracts were not invalid because of the breach of statute. ${ }^{72}$ Each of these cases was decided on the basis of contract law and the policies inherent in that private law field; they did not touch the problems that are involved in enforcement of a statute designed to strengthen citizen control of government.

Furthermore, the Adler court did not deal with the most relevant California authority. Two California cases had previously declared action of a city council void for noncompliance with notice requirements for meetings. ${ }^{73}$ In both these cases, no notice was delivered to council members as required by statute, and there was no waiver of notice by the members. The rationale for invalidating the actions taken by the councils at these meetings was that the proceedings were defective. ${ }^{74}$

Though the requirements of notice to council members were not designed to establish public meetings, they were certainly designed to facilitate citizen control of the agencies. If the representatives were not informed of the meeting, they could not act to protect their constituents' rights and interests. For citizen control purposes, the defect in the meetings where there is no notice to members of the body is not significantly greater than where there is no notice to the community. Arguably, then, if there is invalidation for lack of notice to members, there should also be invalidation where there is no notice to the community-where there is a secret meeting. ${ }^{75}$ Also, the California Administrative Procedure Act pro-

71184 Cal. App. 2d at 775, 7 Cal. Rptr. at 812-813.

72 Vick v. Patterson, 158 Cal. App. 2d 414, 322 P.2d 548 (1958); Marconi Wireless Tel. Co. v. North Pac. S.S. Co., 36 Cal. App. 653, 173 Pac. 103 (1918); In re Peterson's Estate, 230 Mmn. 478, 42 N.W.2d 59 (1950); John E. Rosasco Creameries, Inc. v. Cohen, 276 N.Y. 274, 11 N.E.2d 908 (1937). Oppenheimer v. Clifton's Brookdale, Inc., 98 Cal. App. 2d 403, 220 P.2d 422 (1950), however, dealt with the right of a citizen to enjoin the public offense of bribery: It denied that right. While there is no case history allowing such injunctions, the courts in California have allowed citizens to enjoin a public body fron carrying into effect a resolution or ordinance that has not been enacted at a properly held meeting. City of Colton v. City of Rialto, 230 Cal. App. 2d 174, 40 Cal. Rptr. 766 (1964); Baumgardner v. City of Hawthorne, 104 Cal. App. 2d 512, 231 P.2d 864 (1951); City of Orange v. Clement, 41 Cal. App. 2d 497, 183 Pac. 189 (1919).

73 Baumgardner v. City of Hawthorne, suppra note 72; City of Orange v. Clensent, supra note 72. However, one California appellate opinion has sided with Adler on the invalidation issue, and no reasoning was given beyond citing the Adler decision. Claremont Taxpayers Assoc. v. City of Claremont, 223 Cal. App. 2d 589, 35 Cal. Rptr. 907 (1963).

74 City of Orange v. Clensent, $41 \mathrm{Cal}$. App. at $499,183 \mathrm{Pac}$. at 190; Baumgardner v. City of Hawthorne, 104 Cal. App. 2d at 515, 231 P.2d at 866.

75 City of Colton v. City of Rialto, 230 Cal. App. 2d 174, 40 Cal. Rptr. 766 (1964) also invalidated an action of the council taken in violation of a statute requiring that 
vides that the superior court may declare regulations of state agencies invalid where there has been substantial failure to comply with provisions of the act. $^{76}$ Both the Administrative Procedure Act and the judicial decisions invalidating actions taken where there was no notice to council members lead one to believe that failure of state agencies to comply with some public meeting requirements may bring invalidation of action taken at secret sessions.

When action taken is declared invalid, government functions may be severely disrupted. California Governor Edmund G. Brown has said that subsequent ratification or reenactment in a public session of action taken at a secret meeting would not be adequate to remstate the ordinance or resolution, and for this reason he vetoed a bill providing that action taken by local bodies without proper notice of the meeting would be void. ${ }^{77}$ The Governor pointed out that the bill provided that any "action taken" in violation of the act would be void; action taken is defined as any "collective decision . . . or collective commitinent or promise . . ." then argued that any decision "merely ratified" at a public meeting would also be void. ${ }^{79}$ This argument suggests there are two decision processes mvolved. The first process is the informal decision made at a secret meeting and thereby void; the second is the formal ratification. His argument probably is that the validity of the second process cannot affect the invalidity of the first for by the language of the statute they are distinct processes.

This interpretation of the statute is somewhat strained. The two decisions can also be seen as part of one process affecting a single action. The determination of which interpretation of the statute is correct should be based on the policy of the open meeting statutes. If the "cure" were merely a vote in a public meeting without any deliberation, then the Governor's argument that ratification would not cure should be correct. Otherwise ratification would be used to circumvent the policy of the open meeting statute. If the cure reasonably effects the purposes of the public

ordinances of annexation shall not be passed within five days of their introduction. Surely this statute seeks to afford residents of the affected area time to become aquainted with the action and its imphications, and time, if necessary, to prepare to confront the council at least at the meeting where the final decision will be made. This rationale is very similar to that underlying the public meeting statutes.

T6 CAI. Gov'T Code \& 11440. In addition, CAI. Gov'T Code § 11423, providing that "failure to mail notice" shall not invalidate any action taken, implies by omission that failure to comply with other notice requirements is a ground for invalidation.

77 Governor's veto message, Assembly Bill 127, Cal. Legislature, Regular (General) Sess., 2 Assembly Journat 3430 (1961).

78 CAL. Gov'T CODE $\$$ 54952.6.

79 Governor's veto message, 2 Assemaly Journal 3430 (1961). 
meeting statute, the Governor's argument is not appropriate. ${ }^{80} \mathrm{~A}$ proceeding to ratify earlier illegal action would impress on the members of the agency the importance and vitality of the open meeting requirements. Most importantly, sucl a proceeding would bring before the community the decision premises of the representatives and give citizens the opportunity to contribute to the governmental process. Such ratification would effect the goals sought by the policy creating the right of access to governmental information.

\section{II}

\section{GOVERNMENTAI WRITINGS ${ }^{81}$}

A meeting where officials discuss the validity of a report or make decisions based on its contents is not really open if the report is not publicly available. Group governmental decisions occur below the "commission" level; the decisions made at these meetings and the bases for the decisions are often recorded in governmental writings. Since the "open and public" statutes do not cover all these meetings, access to writings is necessary for evaluation of agency activity.

Information contained in governmental writings may also be needed for private purposes. The information may, however, cover aspects of individual lives which are normally disclosed only in compliance with required government reports. The right to access must, then, be limited to encourage full disclosure by persons filing required reports. Also, individual privacy must be respected in establishing rules governing access to such governmental information. In trying to resolve this problem, the legislature has enacted nondisclosure rules for certain writings. ${ }^{82}$ When a writing is not covered by sucl a statute, the courts have established a procedure of weighing the importance of inspection against the harm that would result from disclosure. ${ }^{83}$

\section{A. Categories of Governmental Writings}

Not every writing in the custody of a government official is a "governmental writing." The California Supreme Court has strongly indicated

80 City of Orange v. Clement, 41 Cal. App. 497, 499, 183 Pac. 189, 190 (1919), refused to allow ratification of proceedings that were "no action at all." Other jurisdictions have allowed such a cure; this is the better view. Simpson v. City of Highwood, 372 III. 212, 23 N.E.2d 62 (1939); Territory ex rel. Okla. Gas \& Elec. Co. v. DeWolfe, 13 Okla. 454, 74 Pac. 98 (1903).

81 In this area of the law, terms become confused and overlapping. The word "writing" will be used as the generic term covering "public writings," "public records," "other matters," "documents," "reports," and other terms referring to filed data.

82 See text accompanying notes 118-48 infra.

83 See note 101 infra and accompanying text. 
that where the private character of the government agent's activity dominates its public character, a writing related to the private activity will not be considered governmental. ${ }^{84}$

For inspection purposes, California statutes specify three types of governmental writings: "public writings," "public records," matters."87

Public writings are defined in sections 1888 and 1894 of the Code of Civil Procedure. To be a public writing, a governmental writing must satisfy both these statutes. ${ }^{88}$ Section 1888 requires the public writing to be either "the written acts or records of the acts of the sovereign authority," or "public records . . . of private writings." And section 1894 requires a public writing to be laws, judicial records, other official documents, or public records of private writings.

Public records are not defined by statute. The courts have used different definitions, depending on the context in which the term is used. ${ }^{80}$ The common element in these definitions seems to be finality in the governmental process producing the writing. ${ }^{00}$ It is not necessary to formulate a precise definition of public records because public records and the more inclusive category "other matters" are open to inspection under identical rules. ${ }^{01}$

84 Whelan v. Superior Court, 114 Cal. 548, 46 Pac. 468 (1896). Here, a judgment debtor demanded to see the written instructions given by his judgment creditor to the county sheriff for enforcement of a writ of execution; inspection was denicd. The sheriff for this purpose was said to be "the agent of the party who places the process in his hands ...." Id. at 549, 46 Pac. at 468 . He was not acting in his official capacity, but as a private agent; the writings could not be open to inspection (under former CAL. PoLITICAI CODE $\S 1032$ ) for they were not governmental writings.

85 Cat. Code of Crv. Proc. \$\$ 1888, 1894.

86 CAL. Gov'T CODE § 1227.

87 Ibid.

88 Mushet v. Department of Pub. Serv., 35 Cal. App. 630, 634, 170 Pac. 653, 655 (1917). Examples of public writings are: the copy of a judgment and commitment to state prison, People v. Howard, 72 Cal. App. 561, 563, 237 Pac. 780, 781 (1925); a map filed with the county recorder, Miller v. Murphy, 78 Cal. App. 751, 755, 248 Pac. 934, 936 (1926); a probation report expressly made a part of a judicial record, 24 Ops. Cax. ATT'y Ges. 219, 220 (1954); an investigatory report on county hospitals made by the State Department of Public Health required to be made by CAL. Healtr \& SAFETy Code $\S 1415(\mathrm{~g}), 18$ Ors. CaI. ATT'Y GEN. 231 (1951).

89 In a case involving prosecution for falsification of public records, "public records" were defined as writings "made ... in pursuance of a duty, the immediate purpose of which is to disseminate information to the public or to serve as a memorial of official transaction for public reference." People v. Olson, 232 Cal. App. 2d 480, 486, 42 Cal. Rptr. 760,764 (1965). They have also been defined as writings "required by law to be kept by an officer, or which be keeps as necessary or convenient to the discharge of his official duty ...." in a case involving the admissibility of public records as evidence. People v. Purcell, 22 Cal. App. 2d 126, 130, 70 P.2d 706, 708 (1937).

90 See Coldwell v. Board of Pub. Works, 187 Cal. 510, 519-20, 202 Pac. 879, 882 (1921). 91 CAI. Gov'T CODE \& 1227. 
"Other matters" includes prehiminary estimates and details which form the basis for a final government decision. ${ }^{22}$ Courts have said that other matters must be matters in which the entire public has an interest. ${ }^{93}$ When this rule was announced, however, the inspection statute read: "The public records and other matters in the office of any officer are at all times, during office hours, open to inspection of any citizen of this state." The statute provided no exception to its requirements. To protect individual privacy and internal government administration, it is quite possible the courts felt it necessary to require other matters to be writings of interest to the whole public. Under the current statute, ${ }^{95}$ which specifically provides an exception to inspection, this construction is no longer needed. Without statutory hindrance the courts nay examine the relative need for inspection of the public record or other matter and the detriment that will result from disclosure, and decide by balancing those two considerations whether to allow disclosure. ${ }^{96}$

\section{B. Common Law Rules of Inspection in California}

The general inspection statute, Government Code section 1227, provides: "The public records and other matters in the office of any officer, except as otherwise provided, are at all times ... open to inspection ...." The meaning of this statute is controlled by the meaning of the "except as otherwise provided" clause. Exceptions to inspection have been established by statute and court rule. ${ }^{97}$ This section of the Comment will deal with court-established exceptions to inspection.

At coinmon law every person may inspect if he has a beneficial interest in the governmental writing, and if his interest outweighs the interest of the community in preventing disclosure. ${ }^{98} \mathrm{~A}$ beneficial interest

92 Coldwell v. Board of Pub. Works, 187 Cal. 510, 202 Pac. 879 (1921).

93 Ibid.; Whelan v. Superior Court, 114 Cal. 548, 46 Pac. 468 (1896).

94 CaI. PoliticaI Code $\$$ 1032, replaced by CaI. Gov't Code $\$ 1227$.

95 CAL. Gov't CODE $\$ 1227$.

98 Arguably, the "whole pubic" rule applies only to the facts of the case in Coldwell where the petitioner was a taxpayer. Coldwell v. Board of Pub. Works, 187 Cal. 510, 202 Pac. 879 (1921). The "whole public" test was not necessary for the decision in Whelan. Whelan v. Superior Court, 114 Cal. 548, 46 Pac. 468 (1896).

97 Prior to the enactment of Government Code $\S 1227$, the courts had established rules restricting inspection. There is no indication in the statute that these rules were to be abrogated. Arguably, then, the legislature intended to incorporate court establisbed exceptions to inspection into the general exception clause. Furthermore, CAI. CODE OF Crv. Proc. § 1892, enacted prior to CAL. Gov'T CoDE § 1227, provides for inspection of "public writings . . . except as otherwise expressly provided by statute." The legislature had an opportumity to use similar wording for public records and other matters and did not do so. This strengtheus the argument that court established exceptious were intended to be read into CAL. Gov'T CODE $\$ 1227$.

88 For an exemplary opinion illustrating this principle, see MacEwan v. Holm, 226 Ore, 27, 359 P.2d 413 (1961), and cases collected therein. Mandamus is the proper form 
permitting inspection may be private or public. A private interest would be one that enables the petitioner to maintain or defend an action for which the writing sought would furnisl evidence or necessary information. ${ }^{99}$ A public interest would be that of a taxpayer..$^{100}$ California has apparently adopted these basic common law rules for determining who has the riglt to inspect. ${ }^{101}$ However, Cahfornia's adoption of the common law

of action to compel an official to allow inspection. However, the rules for the issuance of the writ and those allowing inspection have often merged into an indistinguishable whole. Compare, e.g., Conlon v. Orr, 71 Cal. 43, 11 Pac. 814 (1886) with Coldwell v. Board of Pub. Works, 187 Cal. 510, 202 Pac. 879 (1921). Conceptually, it is necessary to show first that the requirements for the writ exist and second that those for inspection are met. Mandamus is a discretionary writ. E.g., Dowell v. Superior Court, 47 Cal. 2d 483, 304 P.2d 1009 (1956). It will issue only when a legal duty is established and there are no other sufficient means for enforcing that duty. Dowell v. Superior Court, suspra. For the writ to issue, the petitioner must show he is beneficially interested in that he has a legal right to relief. E.g., Silva v. City of Cypress, 204 Cal. App. 2d 374, 22 Cal. Rptr. 453 (1962). And he must show that issuance will not result in substantial public detriment. E.g., Ferenz v. Superior Court, 53 Cal. App. 2d 639, 128 P.2d 48 (1942). These requirements for mandamus outhine the general frame of the common law rules for inspection. The law of inspection has particularized the situations when a sufficient beneficial interest exists, and especially when severe public detriment will occur because of disclosure.

99 See, e.g., Nowack v. Auditor Gen., 243 Mich. 200, 219 N.W. 749, (1928).

100 Ibid.

101 In Conlon v. Orr, $71 \mathrm{Cal} .43,11$ Pac. 814 (1886), a writ of mandate was brought by a person asserting a private interest to compel the treasurer of an insane asylum to allow inspection of a writing, allegedly in his custody, assailing the character and conduct of the medical superintendent of the asylum. A demurrer to the complaint was sustained on the ground that the petitioner did not appear beneficially interested in the matter: Such writings are not open to anyone with mere "idle curiosity" and with no motive other than to repeat throughout the community what might be slander. Id. at 44, 11 Pac. at 815 . Runyon v. Board of Prison Terms \& Paroles, 26 Cal. App. 2d 183, 79 P.2d 101 (1938), involved a demand by a person asserting a private interest for letters and commumications sent by various persons to the Board in connection with the hearing and determination of applications of parole. This request was refused. The court said a sufficient private beneficial interest in the petitioner was not established and cited Ruling Case Law, the predecessor of American Jurisprudence, for the proposition that writings involved in the apprehension, prosecution and punishment of criminals shall be deenred not open to public inspection. Id. at 184-85, 79 P.2d at 101. Accord, People v. Wilkins, 135 Cal. App. 2d 371, 287 P.2d 555 (1955). By using Ruling Case Law, common law was explicitly recognized as authority for decision. By weighing the private beneficial interest of the petitioner against the counterinterest of the community in nondisclosure, these courts established the balancing process as the basis for determining whether inspection should be allowed. By strong implication, inspection will be permitted when there is sufficient private beneficial interest and no severe public detriment will result.

In Mushet v. Department of Pub. Serv., 35 Cal. App. 630, 170 Pac. 653 (1917), a taxpayer asserting a public beneficial interest sought to force the defendant to allow inspection of the city power company's books. Analogizing from the principle of common law that the stockholder of a corporation has an inherent right to inspect the corporate books and records because inspection is necessary to protect his interest in the business, the court found sufficient public interest to inspect in the taxpayer as taxpayer. Id. at 636-37, 170 Pac. at 656. A taxpayer's petition for mandamus to permit inspection of preliminary plans and designs of a municipal waterproject was granted for similar 
rules poses an additional problem since the statute allows inspection of "other matters" while the common law rules apply primarily to the more finalized "public records."102 There is, therefore, some question whether the whole common law structure will be adapted to include inspection of other matters.

A person with a public beneficial interest-a taxpayer-can inspect other matters which are of interest to the public as a whole. ${ }^{103}$ Perhaps the most important question undecided by the Cabifornia courts is which other matters a person with only a private beneficial interest can inspect. If he is himited to inspecting only matters which are of interest to the public as a whole, ${ }^{104}$ he has no greater access to information than has the person with a public beneficial interest. Yet his may be an entirely different interest; the writing he seeks may be the best available evidence to sustain his claim or to defend a claim brought against him.

The availability of fimished data gathered by the government to citizens for their private purposes is established. ${ }^{105}$ The need for data, however, may be just as strong or even stronger when that data is in the raw and tentative form of other matters. ${ }^{106}$ The burden arising from persons inspecting other matters for private reasons may be less than the burden that exists under the rule allowing taxpayer inspection of other matters. Administrative disruption may be considerably less than when there is comparable taxpayer inspection. In one case where an individual who claimed only a private beneficial interest demanded inspection, only one letter was desired. ${ }^{107}$ In another case, the petitioner sought letters and communications concerning a single prisoner. ${ }^{108} \mathrm{~A}$ taxpayer, on the other hand, may well have to inspect a great mass of writings to be able to evaluate properly the operation of any government project. ${ }^{108}$

reasons in Coldwell v. Board of Pub. Works, 187 Cal. 510, 202 Pac. 879 (1921). These two cases established the common law taxpayer inspection rule. However, even if the petitioner is a taxpayer, he may not be able to inspect. Mushet suggested that if the petitioner were a competitor of the city enterprise whose writings were to be inspected, no inspection would be allowed. Mushet v. Department of Pub. Serv., supra at 638, I70 Pac. at 657. Similarly, Coldwell reserved judgment on a situation where the petitioner had the improper motive to "mislead or prejudice the public mind" against the public project involved. Coldwell v. Board of Pub. Works, supra at 517, 202 Pac. at 881.

102 See MacEwan v. Holm, 266 Ore. 27, 359 P.2d 413 (1961).

103 Coldwell v. Board of Pub. Works, 187 Cal. 510, 202 Pac. 879 (1921).

104 See text accompanying notes 93-96 supra. See also Comment, Inspection of Public Records Under California Law, 50 CaITF. L. REv. 79, 81-82 (1962).

105 E.g., Brewer v. Watson, 61 Ala. 310 (1878), State, ex rel. Ferry v. Williams, 41 N.J.L. 332, 32 Am. Rep. 219 (1879), Rex v. Lucas, 10 East 236, 103 Eng. Rep. 765 (1808), Rex v. Allgood, 10 East 236, 101 Eng. Rep. 1232 (1798).

106 See MacEwan v. Holm, 226 Ore. 27, 359 P.2d 413 (1961).

107 Conlon v. Orr, 71 Cal. 43, 11 Pac. 814 (1886).

108 Runyon v. Board of Prison Terms \& Paroles, 26 Cal. App. 2d 183, 79 P.2d 101 (1938).

109 The taxpayer cases involved inspection of vast bulks of writings: in Mushet $v$. 
An additional burden resulting from inspection is the possible deterrent to full disclosure on required government reports and the threat to the privacy of the individual. To protect individual privacy and encourage full disclosure, the courts might put appropriate conditions on the inspection and use of the writings sought. ${ }^{110}$ With the courts determining the existence of a beneficial interest and balancing this interest against the burden that inspection will cause, there should not be any sudden flood of people inspecting other matters. Given these safeguards and the potentially strong private interest, the right of access to other matters should not be limited to the interest of the taxpayer but should extend equally to that of the private petitioner. ${ }^{111}$

The common law rules of inspection that have been established in Califorma for public records and other matters are also applicable in some circumstances to public writings. By section 1892 of the Code of Civil Procedure, public writings are open to inspection "except as otherwise expressly provided by statute."

At least one statute allows the courts to develop the same disclosure rules for public writings as for other matters and public records. Section 1881(5) of the Code of Civil Procedure establishes for purposes of evidence law a government nondisclosure privilege for communications made to a public officer in confidence when disclosure would prejudice the public interest. The reasoning in most of the cases which use this statute as the ground for nondisclosure is almost identical to that found under the common law rule established for public records and other matters. ${ }^{112}$ The California Law Revision Commission has described the process as follows: "The judge must determine in each instance the consequences to the public of disclosure and the consequences to the litigant of nondisclosure and then decide which outweighs the other."113

Though the balancing process the court goes through is the same for public writings, public records and other matters, it may be easier to gain

Department of Pub. Serv., 35 Cal. App. 630, 170 Pac. 653 (1917), the "books" and "records" of the company; in Coldwell v. Board of Pub. Works, 187 Cal. 510, 202 Pac. 879 (1921), "plans and designs" of a great public water project.

110 Cf. Cax. Code of Civ. Proc. § 2031.

111 The writings involved in Conlon v. Orr, 71 Cal. 43, 11 Pac. 814 (1886), would definitely be classed as other matters. The decision in that case implied that had a private beneficial interest existed, inspection would have been allowed. Also, the Attorney General has stated that a private beneficial interest may be sufficient standing for bringing a writ for inspection of other matters. 11 OPS. CAx. ATT'y GrN. 41, 44-45 (1948).

112 See, e.g., Chronicle Publishing Co. v. Superior Court, 54 Cal. 2d 548, 568, 354 P.2d 637, 647, 7 Cal. Rptr. 109, 119 (1960); City \& County of San Franciseo v. Superior Court, 38 Cal. 2d 156, 163, 238 P.2d 581, 584 (1951); City Council v. Superior Court, 204 Cal. App. 2d 68, 76, 21 Cal. Rptr. 896, 901 (1962).

113 Caltrornia Law Reviston Commotsion, Recomomendation Proposino an Evmence Code, comment to section 1040 (1965). (Replacing Car. Code of Crv. Proc. § 1881(5)). 
access to public writings than to public records and other matters. In arguing for nondisclosure of public writings under the balancing test, the government must show that the information was originally given in con- . fidence. This is not true of the balancing test for public records and other matters. Therefore, when arguing for nondisclosure of public writings, the burden on the government is higher than when arguing for nondisclosure of public records and other matters.

Rules for inspection of public writings, public records and other matters do not exhaust the inquiry into the general inspection statutes. A set of statutes exists providing that "all records" of specified state agencies "shall be open to inspection by the public." vide for any exception to inspection, in contrast to statutes applicable to all government agencies establishing inspection rights for public writings, public records and other matters. Arguably, the legislature established a new category for inspection by the use of the term "records." Because of the existing confusion about the precise extent of the present categories, ${ }^{115}$ this is improbable. One could argue, however, that the statutes do establish a category of state agency governmental writings with no exception to inspection because the legislature simultaneously enacted a number of statutes providing that "all records" of specified agencies shall be open to inspection "except as otherwise provided." ${ }^{\text {"116 }}$ Yet, the courts previously have found exceptions to inspection in a statute worded similarly to the ones in question, ${ }^{117}$ and a change in judicial method probably will not occur. The governmental writings of the agencies covered by these statutes should be available for inspection on the same terms as are public records and other matters under the common law rules of inspection.

\section{Legislative Limits to Inspection}

The greatest himitation upon the right to inspection can be found in a mass of statutes prohibiting disclosure of specific governmental writings. Because these statutes are not grouped together in the codes, it is difficult to establish the extent of the right of access granted by the legislature. This type of legislative pattern makes it easy for pressure groups to achieve nondisclosure statutes tailored for their particular interest. This is not to say that all nondisclosure statutes violate the community

114 See, e.g., Cal. Stat. 1957, chs. 2170-2235, and Cal. Stat. 1959, chs. 842-62.

115 See note 89 supra.

116 See, e.g., Cal. Stat. 1957, chs. 2170-2235, and Cal. Stat. 1959, chs. 842-62.

117 Cal. Politrcal Code $\$ 1032$, the predecessor of CaL. Gov'T Code $\$ 1227$, had no exception clause when the first "other matters" cases were being decided. Yet the courts read exceptions into it. E.g., Conion v. Orr, 71 Cal. 43, 11 Pac. 814 (1886). Consequently, it can be argued that the "unequivocal language" of these statutes is not so unequivocal after all. 
will; but that will is easily frustrated by drafting statutes in this manner. The specific nondisclosure statutes have a strong irregularity of language and coverage. Attempts have been made to classify the subject matter of the statutes, ${ }^{118}$ but any such classification is relatively arbitrary and does not draw meaning out of the language. ${ }^{119}$ This section of the Comment will attempt to provide a structure for analysis of these statutes.

\section{Preliminary Considerations}

To be privileged, the writing must come within the express terms of a nondisclosure statute. ${ }^{120}$ This maxim has been reiterated primarily in hitigation involving a statute providing that required automobile accident reports shall be for the "confidential"121 use of the Department of Motor Vehicles. ${ }^{122}$ The leading case ${ }^{123}$ allowed reports to be admitted into evidence even though they were taken by officers in a Highway Patrol station, because they were not made on the requisite forms nor filed according to regulation. ${ }^{124}$ In a more recent case involving property tax exemption records, a district court of appeal reaffirmed that the statutes are to be read strictly in determining what writings are not to be disclosed. ${ }^{125}$

118 Comment, Inspection of Public Records Under California Law, 50 Carr. L. REv. 79, 82 (1962) defined the following categories: sections prohibiting disclosure of specific records except in the performance of official duties to which they relate; statutes prohibiting disclosure of information usually obtained from an examination of private records during an investigation; and statutes giving discretion to officials on disclosure.

Another classification might be one based on the subject matter of the writings involved: physician-patient relationship (e.g., CAL. CIv. CODE § 79.09; CAL. EdUC. CODE § 11901;

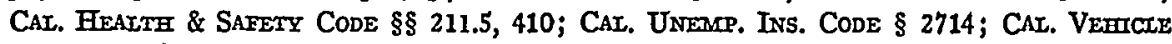
CODE § 1808); exercise of the parens patriae power (e.g., CaL. Crv. Code § 227; Car. Educ. CODE § 10751; CAT. WeLfare \& INST'NS CODE $\$ \S 827,11206,11478,12513,17006)$; internal security of the State (e.g., CAx. REv. \& TAX. CoDE $\$ \S 408,451,754,833,1820$, 7056, 9255, $10406,14813,16563,19282-87,26451-53 \mathrm{c})$; information from the exercise of quasi-regulatory powers (e.g., CAL. AGRIC. Code $\$ \S 1300.13,1300.22$, 2091, 4163, 5603; CAT. CORP. CodE $8 \S$ 25314, 27005; CAL. FnN. Code \$§ 254, 17417, 18610; CAL. INs. CoDE \$§ 735, 856, 1860.3, 11141, 12956; CaI. Gov't Code \& 11183; CaI. PuB. Resources Code $\S \S 2207,3234,6826$ ); intragovernmental activities (e.g., CAL. REv. \& TAX. CODE $\$ \S 646,831,8255,14814,16507$ ); investigation of incidents outside of government (e.g.g CAL. VEBrCLE CODE $\$ \S 16005$, 20012-15, 20833).

119 E.g., within the quasi-regulatory category of note 118, compare Cax. AGric. CodE \& 2091, with § 4163 .

120 Dwelly v. McReynolds, 6 Cal. 2d 128, 131, 56 P.2d 1232, 1234 (1936).

121 Throughout the rest of the paper, the terms used to describe the degree of nondisclosure (the generic term) must be closely watched. The variety of use of these terms has created a maze for the person attempting to interpret these statutes.

122 CaL. Vermcte Code $\S \S 20012-15$ and their predecessors Cal. Stat. 1923, ch. 266, as amended by Cal. Stat. 1931, ch. 1026.

${ }^{123}$ Dwelly v. McReynolds, 6 Cal. 2d 128, 56 P.2d 1232 (1936).

124 Id. at 131,56 P.2d at 1234 . In this case the officers, colleagues of an injured California Highway Patrol officer-plaintiff, did not make the report as required by statute. Over objections that this report was "confidential," defendant's statements were read into evidence.

${ }^{125}$ Gallagher v. Boller, 231 Cal. App. 2d 482, 41 Cal. Rptr. 880 (1965). CAx. REv. \& 
Where the question is who will be permitted to enforce the nondisclosure provisions, strict construction of the statute may not be required. A statute making it a misdemeanor for a government employee to disclose income tax returns ${ }^{128}$ was interpreted by the California Supreme Court to allow the taxpayer to claim privilege for his own office copies of those returns. The court reasoned that the purpose of the section was to facilitate tax enforcement by encouraging taxpayers to make full and truthful disclosures without fear that the information would be used against them for other purposes. ${ }^{127}$

\section{Specific Nondisclosure Provisions}

The meaning of nondisclosure terms in any statute depends on the modifying clauses used. Some statutory wording patterns command less disclosure than others. Perhaps the strictest nondisclosure statute is Welfare and Institutions Code section 781 providing that a juvenile court may, on petition of a former ward or probation officer, order "sealed" all records, papers, and exhibits in the case whicl are in custody of the juvenile court and other agencies and officials named in the order. Thereafter, proceedings "shall be deemed never to have occurred" and "such former ward may properly reply accordingly to any inquiry about the events ...." The Attorney General has said that the term "seal" and the ability of the former ward to deny the occurrence of the reported events mean that to any imquiry the agency must reply it has no knowledge of an individual's "record" even though the agency has custody of the writing. ${ }^{128}$ There can be no greater safeguard against disclosure than denial that the records exist. ${ }^{128}$

Welfare and Institutions Code section 10850 provides:

[A]Il applications and records covering any individual . . . relating to

TAX. CODE $\S 451$ provides that there shall be no public inspection for records not "kept or prepared" by the assessor. In Gallagher, the assessor, who was resisting inspection, claimed that the applications for tax exemption, though in the files of his office, were not "kept" by him and therefore were not open to inspection. The court said his argument was essentially that "kept or prepared" should be interpreted as "kept and prepared." Gallagher v. Boller, supra at $488,41 \mathrm{Cal}$. Rptr. at 884 . But if the legislature had intended to restrict the records which were open to inspection to those prepared by the assessor, there would have been no point in using the alternative conjunction. Ibid.

126 CAL. REv. \& TAX. CODE $§ 19282$.

127 Webb v. Standard Oil Co., 49 Cal. 2d 509, 513, 319 P.2d 621, 624 (1957). Webb has been followed in a mandamus action involving nondisclosure of corporate income tax returns under a nearly identical statute. Aday v. Superior Court, 55 Cal. 2d 789, 362 P.2d 47, 13 Cal. Rptr. 415 (1961).

12840 Ors. CAL. ATt'Y GeN. 50, 51 (1962).

120 But see Application for Examination for Admission to Practice Law, The Committee of Bar Examiners of the State Bar of California, question 19, where a conviction "expunged from the records by order of court" must be disclosed on penalty of perjury. Is a record "sealed" the same as one "expunged?" 
any form of public social services for which grants-in-aid are received by the State from the United States government shall be confidential, and shall not be open to examination for any purpose not directly connected with the administration of such public social service; provided, however, that any agency . . . may make the disbursement records available to the district attorney upon his request. The information thus obtained shall be made available to the district attorney for the official conduct of his office and shall not be used for any other purposes.

In this statute, "confidential" apparently means that the writings shall not be inspected except for a purpose "directly connected with the administration" of the service. This meaning of the word "confidential" has been adopted by the Attorney General in two opinions dealing with the ability of a citizens' advisory board to inspect writings covered by section 10850 and an opinion dealing with the right of the grand jury to inspect such writings. ${ }^{130}$

Presumably the meaning of "confidential" for the purposes of this statute is also qualified by the ability of the agency to make disbursement records available to the district attorney. Unfortunately, the statute offers no clue to the meaning of the "official conduct" to which the use of these records is limited. If the district attorney uses the information and writings in an indictment proceeding before a grand jury, ${ }^{131}$ can he use them after an indictment has been returned? This would be within the "official conduct" of his office; yet the information might be inserted into the trial record, a public writing open to inspection. Such a disclosure seems contrary to the implied intent of the statute that the information gathered be revealed only to those involved in the administration of the services. Arguably, prosecution of persons who violate the welfare laws is part of such direct administration, but there is no provision that "official conduct" is limited to this type of prosecution. ${ }^{132}$

Problems of precise limitation on the district attorney pale in light of the realization that, regardless of the limitations of the statute, the practice of the agency has been to violate them in some important cir-

13041 Ors. Cat. Atr'y Gen. 51 (1963), 40 Ops. Cat. AtT'y Gen. 57 (1962), and 9 Ops. CaI. AtT'y Gen. 45 (1947).

131 See text accompanying notes 142-145 infra.

132 The Attorney General read another, not quite to be expected, modification of "confidential" into the statute when he said that the writings covered by the statute were to be available to Selective Service Boards. Using the phrase that limits the operation of the statute to services supported by federal grants, he said that the legislative history of the statute indicated a desire to comply with the requirements of the Federal Social Security Board; the Board had provided that the Selective Service should have access. 2 Ors. Cax. ATr'Y GEN. 497 (1943). There is no indication on the face of the statute that federal rules control state nondisclosure policy. This opinion was written in 1943; war needs could well have been the major factor in the Attorney General's decision. 
cumstances. The former chairman of the Board of Social Welfare candidly wrote in the California Law Review that the Board has "always discussed in public meetings facts and policies involved in the appeals brought by individuals, and it has done so referring to case by name and not just number."133 $\mathrm{He}$ justified this action by claiming that "the chance that anybody will be present other than officials who will connect naines and data given with persons known to them is very small indeed."134 Under such practices, the nondisclosure statute is of little value, particularly given the possibility that the courts inay consider disclosure at this meeting as a waiver of nondisclosure for all purposes. ${ }^{135}$

A nondisclosure phrase different from that found in Welfare and Institutions Code section 10850 appears in a number of statutes; this phrase reads that a specified writing is "not a public document and is not open to public inspection."136 The statutes do not define "public document" nor "public inspection." Three Attorney General's opinions have interpreted statutes forbidding "public inspection" where the petitioner was another California government unit. One opinion concludes that legislative committees inay inspect such writings if the resolution creating those committees specifies or necessarily implies an investiga-

133 tenBroek, Welfare in the 1957 Legislature, 46 CALIF. L. REv. 331, 358 (1958).

184 Id. at 359.

185 Once a writing has been opened to inspection, it is no longer privileged. Coldwell v. Board of Pub. Works, 187 Cal. 510, 522, 202 Pac. 879, 884 (1921). Waiver may be by government body-Coldwell v. Board of Pub. Works, supra; 16 Ops. CAL. ATr'y GeN. 76 (1950)-or private persons allowed to claim the privilege, Crest Catering Co. v. Superior Court, 62 Cal. 2d 274, 42 Cal. Rptr. 110, 398 P.2d 150 (1965); Vogan v. McLaughlin, 172 Cal. App. 2d 65, 342 P.2d 18 (1959). See also Oleander v. United States, 210 F.2d 795 (9 Cir. 1954).

Private persons probably cannot waive the government's privilege covering the same writing, cf. California Law Revision Comanission, Recomamendation Proposing an EviDENCE CODE, Comments to $\$ 1040$ (1965). Knowledge of the statutory claim is not a requirement for waiver. See Oleander v. United States, supra. And waiver may be contracted for in advance. See Crest Catering Co. v. Superior Court, supra. Waiver does require inspection, and a mere cursory look at the writings, amounting to a "windfall," will not necessarily quahify. See Burwell v. Teets, 245 F.2d 154 (9th Cir. 1957).

Whether a waiver given to one category of potential inspectors extends to other categories has not been discussed by the courts. This probably should not be the rule. For example, waiver by allowing inspection by another government body, cf. text accompanying notes 136-41 infra, might bring benefit to the general public, whereas inspection of the same writings by private persons might act to the great detriment of the public welfare with only small corresponding benefit. Consequently, the courts should weigh the benefits and detriment involved to decide if a particular waiver is a waiver for all purposes.

A severe problen, untouched by the courts, is how a person seeking to inspect can determine if there has been a waiver. A balancing process by which waiver would not necessarily cause disclosure of the writings for all purposes might lessen any tendency of officials to keep waiver secret.

130 E.g., CaL. Rev. \& TaX. Code $§ 451$. 
tion of this material. ${ }^{137}$ The reason for this conclusion is probably that the legislature could always change the classification of nondisclosure by statute. A second opinion stated that the Department of Finance could not examine the writings in the custody of the State Board of Equalization covered by such a statute ${ }^{138}$ where inspection would lead to no constructive recommendations but would only create friction between the two departments. ${ }^{130}$ This may indicate that the Department is a member of the "public" for nondisclosure purposes. Alternatively, the opinion may merely be reiterating the determination that there can be no inspection where the community interest as a whole will suffer. ${ }^{140}$ The third opinion concluded that county assessors were also not allowed to inspect writings of the State Board of Equalization. ${ }^{141}$ The implication that the Attorney General felt the assessors were menbers of the "public" for nondisclosure purposes is stronger in this opinion than in the preceding one. This is a very strange reading of "public." It seeins more reasonable that the purposes of the statute were to prevent nonofficials from inspecting the writings, and that the particular wording was chosen by the legislature to indicate that officials with legitimate purposes would be allowed to inspect.

Not all nonlegislative governmental units have been considered members of the public under statutes that prohibit public inspection. The San Francisco grand jury was allowed to inspect writings covered by a nonpublic inspection statute in the course of its investigation of the county assessor's office. ${ }^{142}$ The city attorney of San Francisco argued that the pohicy of protecting the maker of the report, and thus encouraging full revelation, would not be harmed by this investigation. ${ }^{143}$ The contents of writings revealed to the grand jury would not become public information "except for those relevant to an indictment," for the grand jury is precluded by the Penal Code from any disclosure. ${ }^{144}$ Also justifying disclosure to the grand jury in the view of the city attorney is its statutory duty to examine the accounts and records of all county officers, especially those writings pertaining to revenue. ${ }^{145}$

The city attorney's conclusion that writings relevant to an indictment could be disclosed is an interesting modification of the statutory phrase "not open to public inspection." One could argue that the writings could

13719 Ops. Car. Atr'y Gen. 18 (1952).

138 CaL. REv. \& TAX. CODE $\$ 833$.

1392 Ors. Cat. Atr'y Gen. 71 (1943), and 2 Ors. Car. Atr'y Gen. 74 (1943).

140 See note 98 supra on the issuance of the writ of mandamus.

1412 Ofs. Car. AtT'y Gen. 244 (1943).

142 San Francisco Chronicle, Aug. 14, 1965, p. I (final home edition); id., Aug. 19, 1965, p. 1 (final home edition).

143 Opinion number 65-22, City Attorney of San Francisco, Aug. 9, 1965.

144 CaI. Pen. Code $\$ 924$.

145 Car. Pen. Code $\$ 925$. 
be disclosed to persons with a different interest from that of the general public. The district attorney's need for the information in prosecution would give him a stronger and different interest from that of the general public. The same might be true for the court hearing the case. That disclosure in court might put the information into a public writing could be treated as of secondary importance because the information might be the heart of the evidence in an important criminal prosecution. The same argument cannot be made for a private hitigant. However, a private litigant might claim that he is in a different position than the general public, and therefore slould be allowed to inspect writings "not open to public inspection." If the purpose of the statute is to limit inspection to governmental units having a need to know, such a litigant should not gain access. But if the purpose of the statute is to restrict inspection to those with a greater need to know than would suffice under the general inspection statutes, a sufficiently strong case might cause a court to allow a private litigant to inspect.

Finally, another type of nondisclosure provision is that which gives a court or a nonjudicial official discretion to order disclosure. ${ }^{148} \mathrm{~A}$ court's clear abuse of discretion may be reversed on appeal, ${ }^{147}$ and the same power of judicial review should be available where statutes give discretion to a nonjudicial government official. ${ }^{148}$ There is no reason to give these officials more power than the courts to determine who will liave access to writings. There is every reason to give them less power and subject them to closer scrutiny, for they may have a personal interest in not allowing access to information which concerns their own governmental agency or body.

\section{Remedies of Private Persons When Officials Violate a Nondisclosure Statute}

A writ of mandamus or a tort action are the remedies available to the person larmed by an official's disclosure of information in violation of statutory provisions.

146 E.g., Cax. Crv. Cone $\& 227$, CaI. Ins. Code § 12956.

147 Hubbard v. Superior Court, 189 Cal. App. 2d 741, 11 Cal. Rptr. 700 (1961). In this case an alternate legatee under a will probated in New York charged irregularities in the California adoption proceedings of other legatees. To substantiate these charges, he petitioned the superior court for disclosure of the papers accumulated in the adoption proceedings under Civil Code $\$ 227$ providing that inspection by nonparties may be allowed by the superior court. Because the adoption decrees were not open to collateral attack in New York by reason of the full faith and credit provision of the Constitution, id. at 749, $11 \mathrm{Cal}$. Rptr. at 705, and because disclosure might cast doubt on the right of inheritance of the adopted children in probate proceedings in other states of no intcrest to the petitioners, id. at 745, $11 \mathrm{Cal}$. Rptr. at 702, the appellate court ruled that the superior court had abused its discretion, and inspection was not allowed.

148 See Stratford Factors v. New York State Banking Dept., 10 App. Div. 2d 66, 197 N.Y.S.2d 375 (1960). 
A writ of mandamus is the proper remedy to prevent an official from violating a statute requiring nondisclosure. To maintain the action, the petitioner might well have to show a beneficial interest, ${ }^{140}$ but if the statute forbids disclosure to the person seeking it and there is a strong probability that harm will result, there should be little trouble establishing this interest. ${ }^{150}$

Where the mandamus remedy would be too late, at least one California case indicates a tort action may be available against the official who violated the statute. ${ }^{151}$ In that case, the court held that violation of a statute establishing the mandatory duty of nondisclosure deprived school officials of the defense of sovereign immunity and subjected them to individual suit. ${ }^{152}$ The court also noted that the officials' error was not in good faith. ${ }^{153}$

The legislature has since enacted rules governing liability of public employees which explicitly state that error while acting with "due care" will not bring liability for violation of a mandatory statute. ${ }^{154}$ Also, under the new statutory scherne, if an employee acts in good faith and without malice under the apparent authority of an inapplicable statute, he is no more liable for his acts and omissions than if the statute were applicable. ${ }^{155}$ To recover, the plaintiff must at least prove lack of due care in the act of disclosure. If the defendant says he acted under a statute other than that allegedly violated, the plaintiff must prove either lack of good

149 See note 98 supra.

150 Where a nondisclosure statute provided that the judge of the superior court had discretion to disclose certain writings and did not provide any remedy for abuse of discretion (CAI. CIV. Code § 227), the standing of the parties to contest the decisions of the superior court to allow disclosure was not questioned. Hubbard v. Superior Court, 189 Cal. App. 2d 741, 11 Cal. Rptr. 700 (1961).

151 Elder v. Anderson, 205 Cal. App. 2d 326, 23 Cal. Rptr. 48 (1962). This case was an action for libel against trustees of a high school district for harm resulting from prohibited disclosure. Behavior of the minor child of plaintiff prompted the trustees to mail an announcement to the public declaring a meeting to bring "full focus" on the "serious violation of manners, morals, and discipline" by this child. Id. at 328, 23 Cal. Rptr. at 49. The announcement then went into detail of the conduct that prompted this meeting. Plaintiff alleged that the action violated CAL. EDUc. CODE $\$ 10751$; that this statute established a ministerial duty; that violation of the statute ehminated the defense of sovereign immunity for the trustees; and that they could thus be sued in tort as individuals, not as trustees.

152 Id. at 336, 23 Cal. Rptr. at 54.

153 Id. at 333-34, 23 Cal. Rptr. at 53. See generally York v. Story, 324 F.2d 450 (9th Cir. 1963).

154 Cat. Gov't CoDe $\S 820.4$ provides that "A public employee is not hable for his act or omission, exercising due care, in the execution or enforcement of any law." CAr. Gov'T CODE $\S 820.2$ provides that "whether or not ... discretion be abused" a public employee will not be liable for injury resulting from an exercise of discretion vested in him. Consequently, only violation of mandatory duties can bring liability.

155 CAL. Gov'T CODE § 820.6. 
faith and malice in the use of that statute or lack of due care under that statute. Such hmitation of liability is necessary, for without this protection, the potential hability of public employees would tend to restrict disclosure of writings. When officials are secretive by nature, and statutes are difficult to interpret, the possibility of tort liability for disclosure even though the official acted with due care would greatly restrict the right to inspect.

\section{CONCLUSION}

An examination of the roles of the different governmental institutions in providing access to information shows the strengths and weaknesses of the rules presently governing such access. The legislature has been the fount of legal authority for access to governmental information in California, yet its initial policy has given way to pressures for secrecy. Most sustained pressure for closed meetings comes from nonjudicial officials. Given the tradition of responsibility to the electorate, the legislature has not appreciably yielded to these pressures; lowever, it lias set forth a less clear policy of openness than might otherwise exist. This can best be seen in the aftermath of the Adler decision, wliere the legislature acted to counter the decision but did not act unequivocally. The new statutes did, however, provide a ground for reasonable arguments that would establish the statutory goal of open and public meetings.

Interestingly, the Attorney General has been the person who has prodded officials to hold open and public meetings. That most of his opinions apply to local legislative bodies and not to state agencies may have caused his preference for openness. Also, perhaps because he heads a bureaucratic organization, lie is able to evaluate effectively the plaints for secret meetings.

Contrast with this action of the legislature and the Attorney General the courts' stifling of the right to access to meetings. The Adler decision was bad law; yet all courts that have since reviewed the problem have followed that court's restrictive attitude. Courts are themselves notoriously secretive; no outsider may attend the decision-making process and no explanation of decisions beyond the written opinion is given. This is not the most fecund soil for developing the right to access.

The courts have a different attitude toward writings. By adapting the common law rules to Cahfornia statutory conditions, they have allowed inspection of a great variety of writings. Only in defining "other matters" have the courts been restrictive; and because of the change in the governing statute, this particular restriction is no longer needed to prevent liarm to the community. The Attorney General in implementing the right to access to writings has demonstrated none of the imagination 
and vitality he exhibited for meetings. The strong actions of the courts and the consequent weight of precedent probably wrought this more conservative action.

The legislature has been most susceptible to pressures for secrecy in the area of writings. It has enacted a myriad of statutes which protect special interests by providing for nondisclosure. The statutory treatment of nondisclosure is far from satisfactory. The multitude of diversely worded statutes creates great uncertainty for lawyers and officials. Though the courts have set down some basic statutory construction rules, they are not very satisfactory. Not enough cases have come to the appellate level for there to be a solid body of interpretation available for guidance. The lawyer and the official are thus forced to rely on their own interpretation of a given statute. The official's interpretation will often be more restrictive than that of the lawyer seeking information, and conflict between them is unavoidable. Court procedures are expensive and time consuming; the fight for a particular writing may be abandoned in the interests of economy even when eventual victory seems certain. Behind all this difficulty is the suspicion that the language of the statutes exists because of drafting whim, and that there has never been any correlative investigation by the legislature of the wording and of the meanings of the language involved. Yet these confusing specific nondisclosure statutes are essential to understanding the exact extent of the right of access to governmental writings. To fulfill its responsibility to the coinInunity and make mtelligible the scope of access, the legislature should review and reorder the specific nondisclosure statutes. 